Please do not remove this page

RMIT

UNIVERSITY

\title{
Delivering social housing: examining the nexus between social housing and democratic planning
}

Legacy, Crystal; Davison, Gethin; Liu, Edgar

https://researchrepository.rmit.edu.au/esploro/outputs/9921860427701341/filesAndLinks?institution=61RMIT_INST\&index=null

Legacy, C., Davison, G., \& Liu, E. (2016). Delivering social housing: examining the nexus between social housing and democratic planning. Housing, Theory and Society, 33(3), 324-341.

https://doi.org/10.1080/14036096.2016.1145133

Document Version: Accepted Manuscript

Published Version: https://doi.org/10.1080/14036096.2016.1145133

Repository homepage: https://researchrepository.rmit.edu.au

(c) 2016 IBF, The Institute for Housing and Urban Research

Downloaded On 2023/04/26 23:55:25 +1000 
Thank you for downloading this document from the RMIT Research Repository.

The RMIT Research Repository is an open access database showcasing the research outputs of RMIT University researchers.

RMIT Research Repository: http://researchbank.rmit.edu.au/

\section{Citation:}

Legacy, C, Davison, G and Liu, E 2016, 'Delivering social housing: examining the nexus between social housing and democratic planning', Housing, Theory and Society, vol. 33, no. 3, pp. 324-341.

See this record in the RMIT Research Repository at: https://researchbank.rmit.edu.au/view/rmit:36177

Version: Accepted Manuscript

Copyright Statement: (c) 2016 IBF, The Institute for Housing and Urban Research

Link to Published Version:

http://dx.doi.org/10.1080/14036096.2016.1145133

\section{PLEASE DO NOT REMOVE THIS PAGE}


Manuscript in preparation for Housing, Theory and Society

Title: Delivering social housing: examining the nexus between social housing and democratic planning

\section{Crystal legacy, Gethin Davison, Edgar Liu}

The construction of social housing in gentrifying neighbourhoods can invoke contestation, revealing tensions between economic imperatives, social policy and neighbourhood change. With a view to understanding how the convergence of these agendas preserve unpopular, but socially critical housing infrastructure, the aim of this paper is to explore how the challenges social housing implementation encounters across these agendas intersect with a broader agenda for local democratic planning. Using social housing as our empirical focus and directing attention to the gentrifying local government area of Port Phillip in Victoria, Australia, this paper reveals how a council's main asset to support implementation - its policy frameworks - creates an urban narrative of social inclusivity and diversity. Through this case we illustrate how elected officials and some residents draw from these policies to interject into episodes of community contestation, which we argue presents opportunities to expose and renew commitments to social housing over space and time.

Keywords: local government, housing policy, democratic planning, social housing 


\section{Introduction}

Project proposals for the development of new social housing can sometimes evoke strong resident opposition and political contestation in planning (Dear 1992; Jacobs et al. 2011; Ruming 2011; Davison et al. 2013). From a planning and housing process perspective, the proposal of a social housing project for instance can incite an immediate and often emotional reaction by neighbouring residents to perceived negative 'impacts' (Inch, 2014). Concerns about decreasing property values and increasing anti-social behaviour (Takahashi and Dear 1997; Powe and Hart 2011; Karsten 2012) combined with concerns about changing neighbourhood character (Davison et al., 2013) make resident contestation at this stage in the planning process a complicated space to negotiate. As governments increasingly connect the provision of social housing with liveability (Hill, 2007; Heylen, 2006), this commitment is oftentimes firmly expressed as a policy commitment in land use and housing strategic policies (Austin et al, 2014). However, at the project proposal stage, this commitment can often be challenged by affected residents and businesses (Nguyen et al, 2013; Sturzaker, 2011). Survey research conducted by Tighe (2012) showed that while a high proportion of people support (in principle) the construction of social housing in their towns and cities, they are often less willing to support its construction in their own neighbourhoods. This is a key challenge for planning generally: How to translate the enthusiasm for social housing offered in the strategic planning stages of planning into the delivery phases.

Urban strategies will frame affordable and social housing as integral to achieving liveable, inclusive and diverse urban environments (e.g. Victorian Government 2014). Yet the discussions about the role social housing plays often cease when social housing proposals are being considered. Instead these discussions are usually forced by affected residents in a haze of emotion reacting to social housing proposals, often in the form of fierce opposition to proposals (Iglesias 2002). The stakes at the project delivery stage - and in the face of opposition - are high. Contestation surrounding the siting of social housing projects can lead to harmful consequences for the project proponent and future residents. The not-for-profit (NFP) sector, which is increasingly active in the construction of social housing, is particularly vulnerable to delays and costs associated with resident opposition to proposed housing projects; the stakes can be even higher for those residents that live in precarious housing arrangements and are most at risk of homelessness. To protect a commitment toward social housing over time and to avoid negative impacts to future residents and providers, there is 
sometimes a propensity to seek out ways to avoid conflict by depoliticising housing delivery altogether. This can be done by narrowing the scope of community engagement to discussions about certain concerns related to a proposed project over others. By drawing upon Mouffe’s (2000; 2005) and Rancière’s (1998) conceptualisation of 'the political', we argue in this paper that the 'political' aspects of social housing - that is opposition against, but also advocacy for social housing - are managed by the formal processes of planning. While this may increase the likelihood of delivery and avoid long drawn out delays, it overshadows how policy commitments towards an inclusive and diverse community can provide a supportive backdrop to engage political contestation (rather than move it to one side). By limiting opportunities for affected residents to discuss how social housing connects with broader policy imperatives to create an inclusive and diverse community, planning as a democratic and deliberative practice is potentially weakened (Purcell, 2006).

In this article, we refer specifically to social housing as a critical form of social infrastructure that supports individuals and families that, without state and/or charitable assistance, are unable to sustain secure tenure. It encompasses public housing (provided by the state) and community housing (provided by not-for-profit and other charitable organisations). The case we highlight in this paper is one concerning a social housing project in metropolitan Melbourne in the Australian state of Victoria. Drawing on the analysis we undertook as part of a much larger research projected funded by the Australian Housing and Urban Research Institute (AHURI) which examined examples of local opposition to affordable housing across three different states in Australia, this paper draws on one of those case studies to reveal how a policy narrative evoking social inclusivity provides a platform to converse upon a commitment to building social housing. This paper reports on a mixed-methods approach, which allowed us to examine the case of the Port Phillip Local Government Area (LGA) in the inner-city area of metropolitan Melbourne, which has a long history of supporting social housing developments and community activism. In this paper we draw on fifteen semistructured interviews with key stakeholders, including representatives of state government housing and planning departments, local government, social housing developers (state, NFP and private developers), housing advocacy groups, as well as community activists directly involved in opposing social housing development. We approached a cross section of individuals from each of these stakeholder groupings who were identified by us through an extensive analysis of policy documents, media, Melbourne newspapers and websites that highlighted the general policy direction regarding social housing in the state of Victoria at the 
time. Interview data was thematically analysed to draw out key narratives which were then worked into chronological order of events. Additionally, a content analysis of 56 written submissions made by members of the public to planning authorities in opposition to social housing proposals was assessed.

\section{Contesting social housing delivery}

The reasons why social housing attracts resident opposition are varied. Oppositional attitudes may manifest from a 'protectionist attitude' to unwanted development (Dear 1992: 288; Devine-Wright 2009) and expressed in terms of negative impact on the quality of life for existing residents on the grounds of an increase in crime, traffic and/or noise, or worsening parking problems (Hogan 1996; National Law Center 1997; Galster et al. 2003). Opposition can also sometimes be expressed in economic terms. Research by Dear (1992), Galster et al. (2003), Cook et al. (2012) and Taylor (2013) show that opponents of social housing are typically wealthy, educated and oftentimes homeowners seeking to defend property investments from any perceived threat. Galster et al. (2003) posit that property values form a proxy for a variety of factors concerning quality of life, and quality of and access to amenities in a neighbourhood. Within this thinking, aspirational residents will be willing to pay a high price for a property in a neighbourhood that has little (real and perceived) crime, traffic or noise, and few problems with parking. Any negative impact on those desirable characteristics, however, will be reflected in a reduction of property values. Individual prejudices directed at affordable housing tenants may also exist (Nguyen et al. 2012), with potential social housing residents at times described as lazy, non-productive, deviant or unworthy.

Concerns for quality of life and property values can be compounded by a fear that the construction of social housing would set a precedent for related development. The overconcentration of social housing is a commonly-raised concern for objectors, citing the potential for the creation of 'ghettoes' (Ruming 2011). The degree of community acceptance of new social housing projects must also be viewed in the context of broader debates about urban consolidation. Planning policy in all major Australian cities currently supports a move towards more compact cities through dual strategies of urban containment and urban intensification (Randolph 2004; Forster 2006). But proposals for higher density development 
are frequently opposed; often on the basis that a proposed development is 'inappropriate' or that the 'character' of a street or neighbourhood would be damaged or destroyed as a result (Lewis 1999; Huxley 2002; Davison 2011; Ruming et al. 2012). As social and affordable housing development often takes the form of medium-density and multi-unit projects, it is sometimes difficult to separate opposition to higher-density development from opposition to social housing developments. Further, because character is inherently both spatial and social (Davison and Rowden 2012), community opposition to a development proposal on the grounds that it comprises the 'wrong' types of buildings can become a cover for opposition because it will house the 'wrong' types of people.

While the reasons that motivate opposition vary, there are two primary ways social housing proposals are typically contested: through formal processes set up by government including public submissions and council meetings; or through informal processes where the formal processes are deemed insufficient or ineffective by residents at responding to concerns and an alternative space to express dissent is embraced. But taken together, both formal and informal spaces exhibit a complex landscape of democratic planning that determine planning outcomes, such as social housing. The formal (government-led planning process), which is often framed as democratic, offers several spaces for concerns to be aired and objections to be lodged (Cook et al. 2012), and it is where the planning system can be used to build legitimacy for difficult planning decisions (Mantysalo et al. 2011). One way it establishes that legitimacy is by integrating participation into the planning process at certain stages. But these processes at the statutory planning stages offer very narrow remits (e.g. design considerations) upon which affected and active citizens can respond (Legacy 2012). The informal spaces, which tend to exist well beyond these formal spaces (Rancière, 1998), is where opposition is redirected, but these are also the spaces where broader discussions (e.g. about the value of locating social housing in a proposed location) can occur. Particularly where community opposition is seen by government agencies to be potentially obstructive or illegitimate the planning system offers inadequate spaces for these kinds of objections and concerns to be heard. Instead, some community opposition to a development proposal can often be described as purely about the objector's self-interest and exhibiting ignorance of the broader societal need for the development: in these cases objectors are often labelled 'selfish obstructionists’ (Gibson 2005). In turn, objectors have their concerns dismissed as NIMBYism (not-in-my-backyard) by development proponents or government agencies that 
wish to undermine what may, in fact, be legitimate arguments (Gibson 2005; Wolsink 2006, 2007).

Sometimes opposition ignites due to the actual planning process. Looking at community opposition to various forms of housing development in California, Pendall (1999) finds that the more burdensome the planning assessment process (the greater the number of discretionary processes involved in the planning assessment process) the more likely it is that a proposal will attract controversy. Conversely, Pendall also shows that affordable housing projects more generally assessed under streamlined planning processes generated less controversy than the average housing project, even though it might be expected that affordable housing projects would generate more. Pendall (1999) argues that this provides hope for social housing advocates and suggests that a strategy for reducing community opposition might be for governments to consider zoning land for multi-unit development and expediting planning assessment for affordable housing proposals, with assessment possibly being made by an independent panel rather than council officials.

Decisions to streamline assessment of proposals and procedures enable the construction of social housing by removing it from possible contestation and 'politics'. However, these efforts to depoliticise social housing construction may only displace opposition to spaces elsewhere, as discussed above (Rancière 1998). The informal spaces where opposition may mount can be the sites for fierce and sometimes very sophisticated opposition campaigns. Contestation may initially manifest in the form of a NIMBY resistance to proposed development, but it is often exacerbated by general persistence of objectors bringing awareness to the proposal and deficiencies in the process to engage widely. Sometimes this is achieved by negative media campaigns that politicise the issue beyond the immediately affected area and may include door knocking and petition signing. Savvy opponents may even focus their efforts on the political systems to raise wider awareness of the perceived injustices affiliated with new housing construction (Davison et al. 2013).

To appease objectors when opposition arises outside formal planning systems, housing providers are increasingly embracing targeted community engagement strategies to address unrest surrounding a proposed development (Davison et al. 2013). Press (2009) and van Alphen et al. (2010) argue that personal contact with future residents can alleviate anxiety directed at certain groups, which in turn may assist in successful social integration into existing neighbourhoods. In some cases this can be led by the housing provider (Pendall 
1999) or developer themselves (Iglesias 2002). Takahashi and Dear (1997) note, however, that the relationship between a community's level of exposure to residents and acceptance of those residents is far more complex and may reference broader ideological objections to the provision of housing subsidy. That is, the objector may be opposed to the subsidisation of housing by government altogether, rather than simply being opposed to a particular development proposal. In seeking to address such an opinion, emphasis in education or public relations campaigns for social housing can be used to re-frame social housing as a means of achieving equality of opportunity for residents (implying that tenants are upwardly-mobile) or achieving economic or other benefits for a neighbourhood, rather than being a welfare intervention (Tighe 2012). These positive messages respond to myths and misunderstandings about social housing and can be a way of dispelling the concerns about possible impacts that often generate local opposition (Nguyen et al. 2012). By using such campaigns and developing media strategies to control the dialogue (Tighe 2010; Jacobs et al. 2011), governments and social housing developers can shift negative perceptions (Galster et al. 2003). But at the very least, it might be that government planners and/or politicians engage in a discussion about affordability and the need for social housing in the neighbourhood and among local people. While considerable attention had been given to how housing providers and government planners seek to manage the narrative about social housing, little has been written about how resident support (when it exists and often occurring beyond the formal planning system) can be used to sustain a commitment to social inclusivity and diversity long term. In the sections that follow we are interested in exploring how this dynamic might play out when formally and informally expressed resident opposition is fierce at the stages of implementation through our case study of Port Phillip in Australia.

\section{The Case of Port Phillip}

In Australia, housing policies have traditionally favoured homeownership over other forms of tenure. Social housing in this housing landscape has remained a relatively small sector, comprising around 5\% of the total stock, though this proportion varies by state and local government area (ABS 2013). The articulation in Australian government policy to increase the social housing stock is stressed by the devolution of responsibility and retrenchment of the sector over successive decades (Dalton, 2009). It is also challenged by a disjuncture in housing policy and urban planning which prevents a neighbourhood focused approach to 
delivering social housing (Ruming et al, 2004). Within this institutional and political context, the Port Phillip City Council (here forth Port Phillip), which is located five kilometres south of the central business district of Melbourne, Australia, has built seventeen social housing projects since 1970 (Press 2009: 8). These seventeen projects represent the highest concentration of social housing construction across all Australian local council areas between 1985 and 2006 (Gurran 2003: 403; CPP 2012a: 8). Since 2011 nearly half of the households in Port Phillip have been earning above median income $(\$ 1,234$ a week or more) with at least $40 \%$ of households with above median weekly income. The percentage of households that live in social housing has gradually declined (though the total number of households who rent socially has not declined), from 5.4\% in 2001 to $4.8 \%$ in 2011. This proportion is now more or less in line with Australian national figure, at $4.7 \%$. This decline can be attributed to a rise in owner-occupation (owned outright or with mortgage), which increased from $25.3 \%$ in 2001 to 40.8\% in 2011 (ABS 2012: 18). Yet, despite such relative affluence and gentrification in recent decades, Port Phillip has continued to support social housing preservation and new construction through a strong framework of related policies.

In addition to a relatively strong history in social housing provision since the 1970s, Port Phillip is also equally celebrated for its long history of active citizen engagement in city planning both through formal and informal means. Examples of citizen contestation around the redevelopment of historic sites and venues in St Kilda, a suburb of Port Phillip, have been well documented (Shaw 2005; Mouat et al. 2013; Legacy et al. 2014). Yet, the active engagement of citizens in their city is not confined to informal protest and agitation. Formal channels to engage citizens have long shaped strategic planning processes, including the large citizen engagement forum that produced the Port Phillip Community Plan (2007). This particular process represented a 'turn' in the depth and inclusivity of citizen engagement sought by an Australian local council. As the Council's primary strategic document, the Community Plan (2007) positions inclusiveness and social diversity as one of the core community values. The Community Plan states that, as a Council area, it acknowledges the "shared responsibility to ensure that everyone, regardless of age or cultural or socioeconomic background, can access services that meet their needs and can participate in community life” (CPP 2007: 10). The policy commitment to support social inclusiveness is further enhanced by the Council Plan. This plan directs the Council’s social activities and is guided by four strategic directions, one of which is "strengthening our diverse and inclusive 
community” (CPP 2012b: 17). Together, the Community and Council plans place diversity and inclusivity at the forefront of Port Phillip’s core values, which are to:

1. Recognise that sustainable communities are socially diverse communities

2. Recognise that affordable and appropriate housing assist in maintaining personal wellbeing and health

3. Encourage community tolerance towards social disadvantage and diversity, and

4. Support policies that are firmly based on social equity and social justice principles.

This matrix of Council policies was developed out of an extensive process of formal community engagement and consultation. This produced policy commitments supporting the retention of existing and the construction of new social housing. The strong commitment to housing affordability and community diversity was articulated through these policies and created a political framework that provided a foundation for politicians and residents to reference.

In the face of a matrix of policy commitments, the most recent decade (2010s) saw Port Phillip confront fierce opposition by local residents directed at social housing proposals including that experienced at Kyme Place, the case study highlighted in this paper. Kyme Place is located just 40 metres from the main street of the Port Phillip suburb of Port Melbourne, at the intersection between a residential zone with a heritage overlay and a business zone (CPP 2009: 30). It abuts an organic grocer, single- and double-story detached homes, and a five-story apartment building. Its original function as a surface off-street car park (with 33 spaces) was highly valued by the local community. In 2007, the local council proposed to redevelop the site into a four-story, 31-unit boarding house (also known as a 'rooming house' in the state of Victoria), with undercover parking facilities built as part of the proposed redevelopment and retained for public use. This redevelopment was seen as a much needed affordable housing option in response to decreasing housing affordability in the local area. As one local politician noted in an interview about the increasing gentrification of the area,

...there was a sense of injustice in my mind that people who had lived and worked in the area can no longer afford to live here.

In support of new construction, in April 2008, the Port Phillip Council commenced a formal statutory planning process to transfer the airspace above the car park to the housing 
association, the Port Phillip Housing Association (PPHA), which would then be responsible for the remediation of the site as well as construction and management of the boarding house. The redevelopment would permit the Council to retain ownership of the site and the public parking spaces on the ground floor of the new building (CPP 2008a). Local Council support was strong for this redevelopment with the then mayor communicating in an April 2008 news release:
All this may sound rather complicated ... but it's not. It's just a smart way of creating some desperately needed community housing by building in air space on an under-utilised car park .... With housing prices through the roof in Port Melbourne, this deal represents one of the few opportunities to secure new affordable housing in the area. It's a win-win situation. Thirty-one single people in need get a roof over their heads (CPP 2008a).

While the process itself was quite transparent, realising the value of the proposed project and keen to see it developed, the Port Phillip Council took unique measures to minimise possible political opposition separating the formal process that had been administered from any agitation that might occur beyond these processes. The community were not engaged in a decision about the siting of the project. Given that this land was considered to be underutilised as a car park, it was earmarked for redevelopment by the Council but; the future use of this site was not open to community debate and engagement. Rather, to appease any potential community concern, the Council developed a "Communications and Stakeholder Relations Plan” (CPP 2008c)which offered a description of the proposal, its objectives, milestones, key stakeholders and an action plan, extending its engagement beyond the basic statutory requirement. Additionally the Council also articulated answers to some potential questions residents and local businesses may ask regarding the project. Further, local residents were provided with seven different opportunities to raise their concerns regarding the redevelopment of Kyme Place (see Table 1). These included public meetings held by the Council, as well as public notifications released by PPHA on the selection process of potential tenants. In line with PPHA policies, tenants to the Kyme Place boarding house would need to demonstrate established links with Port Phillip as either current residents or as key workers that hold employment in the area; this was significant to demonstrate that no new social housing tenants would be moving to the area per se, and that the redevelopment would simply provide more affordable housing options for the existing residents of Port Phillip. 
As per the statutory planning system in Victoria, formal public submissions were also invited, with a large number of submissions received opposing the proposed project. Resident concerns as expressed in the formal submissions reviewed for the Kyme Place redevelopment included overdevelopment of the site, increased crime, and reduced safety and local amenity; the most widely articulated concern was parking and increased traffic (see Davison et al. 2013: 81). In response to this opposition, the Council postponed the transfer of the air space in June 2008 and submitted a development application to its own planning department regarding the development of Kyme Place. As it is both the land owner and the planning approval authority, it was decided that the Council would establish an independent committee to assess the Kyme Place proposal as per section 86 of the Local Environment Act 1989 (CPP 2008b: 2). The independent committee consisted of one local politician, two community members and two paid independent planning experts. These five individuals could also not have made submissions to this proposed project previously and were thus considered to be dispassionate (CPP 2008d). The committee was called the Port Melbourne Affordable Housing Project Planning Assessment Panel (here forth 'the Panel'). This move to establish an independent assessment panel could be seen as one means through which legitimacy could be given both to the process and to the decision to support the redevelopment of Kyme Place, but it could also be viewed as a way of depoliticising the process and appeasing any potential opposition.

Table 1: Community engagement and formal planning process [insert here]

\section{A community in disagreement}

The formal efforts made by the Council to engage community members and to give the process legitimacy could not stop the opposition to the Kyme Place affordable housing proposal from mounting elsewhere. The analysis that follows offers an illustration of the informal engagement by residents and affected groups in the discourse around social housing delivery. What is presented is an account of a politics manifesting beyond and outside of the formal state-led planning processes theorised by Rancière (1998) and more recently by Purcell (2009; 2013) and Metzger et al. (2015). . In the case of the Kyme Place redevelopment, residents and adjacent businesses responded to a lack of discussion around the siting of social housing by informally opposing the proposed development through a 
serious of small-scale protests, letter writing to the MP and letters to the local newspaper. Informal contestation first started to mount locally through the initiative of a local shop keeper who provided the campaign against Kyme Place unfettered access to a large number of people by providing the site for petition signing to those purchasing coffee from the establishment.. As a representative from a local housing organisation told us:

The bakery located next door to the property undertook to advocate against the development by labelling the paper bags (sold with the baked goods) with a sticker stating 'Do you know council intends to turn Kyme Place into public Housing,' and providing the local Member's contact details to voice disagreement.

Disgruntled residents were urged by the shop keeper to engage their local councillor or State Member of Parliament (MP) over their concerns about the project. Residents were activated by messages printed on takeaway coffee cups that said 'Oppose Kyme Place'. When asked to reflect upon the strategies used by this shop keeper to garner support for the campaign against the project, the local State MP said that these strategies were most effective in capturing his attention having received thousands of emails and many phone messages. Reflecting in an interview, this MP stated that these methods were probably the best method of getting the message across that he has seen in the five years in his position as local MP. However, rather than conceding and giving the opponents the political traction they were seeking, the MP instead used those calls to reiterate his support for affordable housing by pointing to the strong policy framework that articulates support for an inclusive and diverse community. Here in this instance, a dialogue opened up between the MP and concerned residents exposing the political nature of social housing. But rather than engage in an antagonistic exchange with no resolution, the MP had the support of the Council's formal policy documents to call upon to engage the opposition rather than dismiss it away:

Affordable housing was always on the council agenda. So I had comfort and support in these particular projects because council had a strong commitment to affordable housing.

Another aspect that contributed to the opposition gaining momentum was the timing of the formal processes and decision-making in line with the 2008 local government election where the project could be formally politicised. Interviewees stated that the atmosphere around the election was highly-charged and that residents positioned the Kyme Place proposal as an 
election issue as several candidates stood on platforms against it. Although this election provided a platform for opposition to be aired, the leverage of the election did not materialise into a defeat of the sitting State MP. Throughout the election this person remained committed to social housing and maintained support for the Kyme Place redevelopment. .

The election provided one pathway to give opposition to the project traction. But it was the discussion that manifested in the local newspaper where the politicisation of the Kyme Place redevelopment formed an opportunity for residents themselves to express a continued commitment openly and publicly to social housing facing down mounting opposition. The Emerald Hill Weekly (EHW), a local newspaper distributed in eight neighbourhoods across Port Phillip, provided a forum for residents to debate the proposed development in 2008. A selection of the letters published in the $E H W$ as shown below offer an illustration of the division amongst residents and local businesses over the Kyme Place redevelopment. One concern emerging and aligning with the oppositional discourse about the project was that planning issues would increase due to the project. Other residents expressed their concern that planning issues were simply being used by objectors to mask concerns about future tenants. The discussion was prompted by a piece written by a local resident who stated his support for the proposal and accused those in opposition to the project to be unwelcoming of diversity:

\section{A taste of diversity}

Opponents of the [Kyme Place development] led by the proprietors of the organic food shop in the area, seem to be saying they are in favour of real food, but not real people.

They want to be part of Port Melbourne without accepting the social and economic heritage that has made the community what it is. Port [Melbourne] has always been an ethnically and economically diverse community .... (Turnbull 2008)

The initial editorial comment opened a space for further response politicising the project, yet its framing forged a provocation and further response by other local residents seeking to defend the provision of social housing and the Kyme Place redevelopment particularly. In the quotation below, a local resident states that the intent of the opposition was to articulate an 
unhappiness towards the Council for a planning process which this resident (and others) believed lacked transparency and time to consider and assess the proposed project's impacts:

House of cards could fall

I object to Noel Turnbull's smug insult (EHW May 21-27) that those opposing Port Phillip Council’s plans for [Kyme Place] are opposed to public housing. But following the indignity of council planning its economic development proposal for [Kyme Place] in secret for nine months and the injustice of it then rushing it through its own planning process, Mr Turnbull’s ill-informed sanctimony is a minor irritant. (Glover 2008)

Other similar articles expressing equally strong sentiments to Mr Glover's appeared in the $E H W$ in the ensuing weeks. In the quotation below, this resident also came to the defence of the opponents by stating that Council's attempt to transfer land into private ownership was misguided:

\section{Nourishing diversity}

Thanks for publishing Noel Turnbull’s ill-informed and naïve letter (EHW, May 21-27). As one of the proprietors of the organic food shop and a member of the newly formed Port Melbourne Alliance, I can say we are all for real food, real people and an ethnically and economically diverse municipality. What we do not abide is the City of Port Phillip's attempt to remove another public asset and transfer it into the ownership of a private entity—-the Port Phillip Housing Association Limited.

Why are we losing more public open space and car parking? Noel, let's make it harder to do business, diminish our economic foundations and see what happens to community diversity then. (Hall 2008)

To these opponents, it would appear that Council failed to effectively communicate to residents that the car park would still remain in public ownership and that the number of parking spots were largely retained. In the absence of effective communication, this led to criticisms of the Council 'illegally' transferring the land of the car park as understood by some local residents. 
The debates that took place on the $E H W$ newspaper were, however, not entirely negative towards the Council's decision to redevelop Kyme Place. The paper provided a forum for some residents to share their support for the development lauding the Council's efforts for wanting to provide more affordable housing options to the local community, as one supporter wrote:

\section{Credit to the council}

I am impressed by the affordable housing units achieved by Port Phillip Council—especially those built into redundant heritage buildings ....

Councillors are committed to increasing affordable housing and do this by using council assets/property as a basis. In Kyme Place, other properties are being sold to finance the units, and the loss of car places is minimal. So despite protestations from Leigh Glover (EHW, May 28-June 3), it seems a case of saying people on low income are not welcome. Retaining our great diversity is an admirable council aim and should be a commitment from every resident. (Grainger 2008)

The views expressed in these letters highlight an important issue: objectors claim that their concerns are about planning issues (parking, scale, over development), but critics of those objectors argue that these planning issues are simply being used to mask underlying opposition to the future tenants. The framing of opposition as focused on the tenants and therefore discriminatory has implications for the perceived legitimacy of the claims being waged. Engagement in the formal planning system limits expression of concern to planning issues. This is perhaps why many resident submission letters analysed in this research preface their objections (and perhaps mask their discrimination of social housing to some degree) with sentences such as: 'while I'm in favour of social housing ...'. Instead the expression of other concerns may get aired outside the formal planning systems. However, when these concerns are discriminatory, the findings presented in this paper offer a refreshing and encouraging sign that this kind of opposition which often gets heavily managed by the planning process can be productively addressed elsewhere.

Earlier we discussed the significance of council policy as a foundation to supporting elected officials in their backing for affordable housing more generally. In addition to these policies, what we are also observing from this debate is resident support for social housing. It is through this debate that the social importance of social housing is reinforced and that the 
momentum of public support achieved at the policy making stage can continue, rather than requiring the planning system to intervene. Supporters of the development were questioning opponents calling for a more detailed examination of why such a project is deemed unacceptable; hence, residents were calling on opponents to justify their displeasure and to engage in an informal and ongoing deliberation about the merits of this project.

In October 2008 another period of public notification and a call for formal submissions was made in response to the proposed development. The initial opposition mounted by local residents and businesses through the submission process led to the Council deferring the land transfer decision until a firm development plan was approved. This allowed additional studies around traffic and car parking, waste management and urban design to be undertaken.

Throughout the multi-faceted statutory planning process, the main concern expressed by local residents and businesses was the loss of car parking. A total of 40 objections were received by the Panel, with concerns ranging from the scale of the development, security of the new undercover public car park, and inadequate space for cars (CPP, n.d.). At the time when the land transfer and planning permit were being sought, it was known that there would be a loss of 11 parking spaces; however the Council believed that they took reasonable efforts to make up for these lost spaces by creating two parking spots in front of the development and 10 spaces along the main street.

Following the redesign, in April 2009 the Panel issued a 'Notice of Decision', which recommended the granting of a planning permit for the Kyme Place redevelopment. The planning permit was finally granted by the Victorian Civil and Administrative Tribunal in September 2009 on the grounds that the redevelopment site would provide the new tenants access to public transport, shops and services and is consistent with the local planning policy framework (CCP 2010: 9; Davison, 2013).

\section{Discussion and conclusion}

The aim of this paper was to examine how the enthusiasm for social housing articulated in the strategic-policy making stages of planning can be maintained into the actual delivery phases. In particular, we focused on how policy documents can be called upon to moderate acute and site specific moments of contestation and to help sustain support beyond the formal planning process. The example of Kyme Place in the City of Port Phillip does not go so far as to offer 
an example of how community contestation and deliberation shapes social housing outcomes; in the case of Kyme Place the formal opposition delayed the project, but neither the formally or informally expressed opposition led to this project not being built. In the end, only a few design amendments were made, and in the face of the opposition, the project was built. Instead, we argue that the case study offers an illustration of how social housing policy and delivery is situated within a much broader context of ongoing political contestation and discourse that manifests in the form of community debate. Here affected residents, businesses, elected politicians and social housing advocates engage in an informal, yet political discussion about sustaining a commitment to diversity and the necessity of critical social infrastructure - in this case, social housing. This raises important normative and theoretical questions about political intervention in periods of opposition and the role that broader community engagement can play through informal, hotly political engagement. Drawing from Purcell (2013) and Rancière (1999), the paper also challenges what democratic planning 'is' and 'ought to be’ (Campbell, 2012). Particularly, what could democratic planning constitute if it was conceptualised as something that also happens beyond, and in addition to, the strict confines of prescriptive legislative requirements. The transition from the plan where social housing goals and targets are articulated to the actual implementation of social housing is itself a political stage in the planning process that affected residents and active citizens engage with. It is political because this transitional stage is when the questions about siting, investment decisions and sequencing of delivery are being decided and where community held values are considered, and in the case of the Kyme Place redevelopment, renewed.

A central tool in the transitional phase remains the policy document. This paper reveals how a council's main asset to support implementation - its policy frameworks - can also be used as the foundation for an urban narrative of social inclusivity transposed by residents in the face of opposition. It could be argued that the history of social inclusiveness communicated through these policy documents and gestured also by the actual development of social housing over a period of two decades, provided the back drop for residents and elected officials to speak out in favour of social housing. When opposition against Kyme Place mounted, and elected officials were lobbied, the policy provided a platform for which politicians could securely state their favourable position. Policy settings and creating a narrative that advocates for an inclusive and diverse community had the advantage of offering support to elected officials - MP and local government councillors alike - who are 
pressed by their constituents. It is here where regressive sentiments about the housing of vulnerable individuals can be directly and publicly addressed and engaged with rather than simply couched as delegitimised dissent (and outside the scope of the planning process to address).

Some immediately affected residents also chose to articulate their concerns for the proposed development. In doing so, they inadvertently invited alternative viewpoints that acted as counter points to the efficacy of social housing development in the council area. This exchange, whilst quite antagonistic in sentiment, enabled the often unspoken sentiments to be aired in a public way. Rather than trying to package opposition into tightly controlled public hearings and submission processes, some residents were engaged in a broad debate about the direction of their community. While some of the language was couched in metaphor, the very difficult issue relating to anti-social behaviour and prejudice was aired and consequently addressed.

What does this case study offer in terms of understanding the relationship between building critical social infrastructure (such as social housing) and fostering a democratic system of planning? Transparency and comprehensibility of the process, and simply providing people with a genuine and timely opportunity to influence decision-making should be taken into account as important principles when such housing developments are proposed. Also, emphasis should be given to the role that tailored education and public relations campaigns delivered by housing providers can play. Consideration should also be given to understanding how these campaigns can promote the positive aspects of social housing development (Tighe 2010), for instance their impact on the local economy (e.g. construction jobs, new employees for the local area), and in improving the appearance of an area (especially where the replacement of unsightly and/or obsolete buildings is involved). As research by Tighe (2012) suggests, many community members do see much value in social housing and that these positive perceptions need to be reinforced in educational and public relations campaigns.

Nonetheless, the provision of social housing, as a form of critical social infrastructure, remains highly political at the local neighbourhood level and more generally across urban regions, attracting negotiations with various interest groups, including developers, each vying for their respective interests (Jacobs et al. 2011). This politicisation is nuanced and extends well-beyond that of NIMBY campaigns, instead reflecting frustration over the process by residents who may find it difficult to have their interests heard (Versteeg and Hajer 2010: 
169). The escalation of opposition to a proposed project may also reflect increasing frustration by residents who might feel that they are being called upon to engage at a point in the process when it is already too late for a genuine discussion about the siting of social housing and other options. At this mature stage in the process, precluded from ongoing discussions are the different ways that neighbourhoods are changing in the face of growing population pressures and how the need for subsidised, affordable housing will increase.

While we make the case in this paper that local democracy should matter and that our framework for thinking about the politics of social housing should move beyond a narrow focus on NIMBY opposition, we draw on Tissot (2014: 1193) and acknowledge that residents living in gentrifying neighbourhoods, like Port Phillip, sometimes do find ways to further limit and control the proportion of 'others' living in the area, whilst still embracing diversity as an inherent value. But we want to conclude by saying that a flourishing local democracy that uses deliberation (both supported formally through the planning process and derived informally by active residents) can help to renew and extend an active commitment to social housing beyond the pages of the policy texts. In the case of Kyme Place, the presence of a strong policy framework prevented politicians and planners from leveraging opposition for unrelated political purposes, as seen in other cities we examined as part of our work (see Davison et al, 2013). Equally, the political commitment to social housing was strongly embedded in the core policy of the council which could in turn support any advocacy in favour of social housing that might emerge. Finally, the case of Kyme Place offers an illustration of the value of the established council policy frameworks in providing a tool for elected officials and some residents to use to interject into episodes of community contestation, which we argue presents opportunities to expose and renew commitments to social housing over space and time. 


\section{References}

ABS (2012) Time Series Profile. Australian Bureau of Statistics, Canberra.

ABS (2013) TableBuilder Pro. Australian Bureau of Statistics, Canberra.

Austin, P. M., Gurran, N., \& Whitehead, C. M. (2014). Planning and affordable housing in Australia, New Zealand and England: common culture; different mechanisms. Journal of Housing and the Built Environment, 29(3), pp. 455-472.

Campbell, H. (2012) Planning to Change the World: Between knowledge and action lies synthesis. Journal of Planning Education and Research 32(2), pp. 135-146.

Cook, N., Taylor, E., Hurley J., and Colic-Peisker, V. (2012) Resident third party objections and appeals against planning applications: Implications for higher density and social housing, Final Report 197, Melbourne: Australian Housing and Urban Research Institute CPP (2007) City of Port Phillip Community Plan, 2007-17. Melbourne: City of Port Phillip. CPP (2008a) News Release: Community housing plan for car park airspace. Melbourne: City of Port Phillip.

CPP (2008c) Communications \& Stakeholder Relations Plan: Updates 16 April 2008. Melbourne: City of Port Phillip.

CPP (2008d) Port Phillip City Council Instrument of Delegation to a Special Committee by the Council, Port Melbourne Affordable Housing Project Planning Assessment Panel: Term of Reference. Melbourne: City of Port Phillip, Organisation Systems and Support.

CPP (2009) Advice concerning public notice of application for planning permit: Kyme Place. Melbourne: City of Port Phillip, Planning and Building Services.

CPP (2010) Ordinary Meeting of Council. 22 February 2010. Melbourne: City of Port Phillip. http://www.portphillip.vic.gov.au/default/2_-_Proposed_Land_

Transfer_to_Port_Phillip_Housing_Association_for_Community_Housing.pdf, accessed 27 March 2013.

CPP (2012a) Strengthening partnerships with local community housing organisations—Draft Strategy, July 2012. Melbourne: City of Port Phillip.

CPP (2012b) City of Port Phillip Council Plan 2009-2013. Melbourne: City of Port Phillip.

CPP (n.d.) Background information-Kyme place.

http://www.portphillip.vic.gov.au/Background_Information_Kyme_Place.htm, accessed 27 March 2013.

Dalton, T. (2009) "Housing Policy Retrenchment: Australia and Canada compared." Urban Studies ${ }_{2}$ 46(1), pp.63-91. 
Davison, G, Legacy, C, Liu, E, Han, H, Phibbs, P, van den Nouwelant, R, Darcy, M and Piracha, A (2013) Understanding and addressing community opposition to affordable housing development, Final Report No. 211, Melbourne: Australian Housing and Urban Research Institute.

Davison, G. (2011) An Unlikely Urban Symbiosis: Urban Intensification and Neighbourhood Character in Collingwood, Vancouver. Urban Policy and Research 29(2), pp. 105-24.

Davison, G. and Rowden, E. (2012) There's Something about Subi: Defending and Creating Neighbourhood Character in Perth, Australia. Journal of Urban Design, 17(2), pp. 189-212.

Dear, M. (1992) Understanding and Overcoming the NIMBY Syndrome. Journal of the American Planning Association, 58(3), pp. 288-300.

Devine-Wright, P. (2009) Rethinking NIMBYism: The role of place attachment and place identity in explaining place-protective action. Journal of Community \& Applied Social Psychology, 19(6), pp. 426-41.

FCDC (2010) Inquiry into the adequacy and future directions of public housing in Victoria, Family and Community Development Committee, Parliament of Victoria, September.

Forster, C. (2006) The challenge of change: Australian cities and urban planning in the new millennium. Geographical Research, 44(2), pp. 173-82.

Galster, G., Tatian, P.A., Santiago, A.M., Pettit, K., and Smith, R.E., (2003) Why Not In My Backyard? Neighborhood impacts of deconcentrating assisted housing. New Brunswick, New Jersey, Center for Urban Policy Research.

Gibson, T.A. (2005) NIMBY and the Civic Good. City \& Community, 4(4), pp. 381-401.

Glover, L. (2008) House of cards could fall-Letter to the Editor. Port Melbourne: The Emerald Hill Weekly.

Grainger, P. (2008) Credit to the Council—Letter to the Editor. Port Melbourne: The Emerald Hill Weekly.

Gurran, N., (2003) Housing Locality: Positioning Australian local government housing for a new century. Urban Policy and Research, 21(4), pp. 393-412.

Hall, B. (2008) Nourishing diversity_-Letter to the Editor. Port Melbourne: The Emerald Hill Weekly.

Hill, J. (2007) Ends and means: The future roles of social housing in England, ESRC Research Centre for Analysis of Social Exclusion.

Heylen, K. (2006) "Liveability in social housing: Three case studies in Flanders", paper presented at the European Network for Housing Research Conference, Ljubljana, Slovenia. 
Hogan, J. (1996) Scattered-site housing: characteristics and consequences. Washington: US Department of Housing and Urban Development.

Huxley, M. (2002) This suburb is of value to the whole of Melbourne. Melbourne: Swinburne University of Technology, Institute for Social Research Working Papers Series, 6, pp. 4-23.

Inch, A (2014) Ordinary citizens and the political cultures of planning: In search of the subject of a new democratic ethos, Planning Theory, pp. 1-21.

Iglesias, T. (2002) Managing Local Opposition to Affordable Housing: A New Approach to NIMBY. Journal of Affordable Housing \& Community Development Law, 12(1), pp. 78-121.

Jacobs, K., Arthurson, K., Cica, N., Greenwood, A., and Hastings, A. (2011) The stigmatisation of social housing: findings from a panel investigation, Final Report 166, Melbourne: Australian Housing and Urban Research Institute.

Karsten, N. (2012) Explaining and Justifying Authoritative Decisions: The Case of Controversial Facilities for the Homeless in Rotterdam, Local Government Studies, 38(2), pp. 143-60.

Legacy, C. (2012) Achieving legitimacy through deliberative plan-making processes lessons for metropolitan strategic planning, Planning Theory and Practice, 13(1), pp. 71-87.

Legacy, C, March, A and Mouat, C (2014) Limits and potentials to deliberative engagement in highly regulated planning systems: Norm development within fixed rules, Planning Theory and Practice, 15(1), pp. 26-40.

Lewis, J. (2008) 'Critics laughed off stage’, The Emerald Hill Weekly, Port Melbourne.

National Law Center (1997) Access delayed, access denied: local opposition to housing and services for homeless people across the United States. Washington D.C.: National Law Center on Homelessness and Poverty.

Nguyen, M.T., Basolo, V. and Tiwari, A. (2012) Opposition to Affordable Housing in the USA: Debate Framing and the Responses of Local Actors, Housing, Theory and Society, pp. $1-24$.

Mantysalo, R., Saglie, I.-L., and Cars, G. (2011) Between input legitimacy and output efficiency: defensive routines and agonistic reflectivity in Nordic land-use planning, European Planning Studies, 19(12), pp. 2109-2126.

Metzger J, Allmendinger P and Oosterlynck, S (eds) (2015) Planning Against the Political: Democratic Deficits in European Territorial Governance. New York: Routledge.

Mouat, C., Legacy, C. and March, A. (2013) The problem in the solution: Testing agonistic theory's potential to recast intractable planning disputes, Urban Policy and Research, 31(2), pp. 150-66. 
Pendall, R. (1999) Opposition to Housing: NIMBY and Beyond. Urban Affairs Review, 35(1), pp.112-36.

Powe, N.A. and Hart, T. (2011) Housing development and small town residential desirability: Valued aspects, resident attitudes and growth management, Town Planning Review, 82(3), pp. 317-40.

Press, M. (2009) Community Engagement and Community Housing: Lessons and practical strategies for Local Government for responding to contested community housing proposals. Melbourne: City of Port Phillip.

http://www.portphillip.vic.gov.au/Final_report_version_4_Sep09_(3).pdf.

Purcell, M. (2006) 'Urban Democracy and the Local Trap', Urban Studies, 43(11), pp. 192141.

Purcell, M. (2009) 'Hegemony and difference in political movements: Articulating networks of equivalence’, New Political Science 31(3), pp. 291-317.

Purcell M. (2013) 'To inhabit well: Counterhegemonic movements and the right to the city', Urban Geography 34(4), pp. 560-574.

Rancière, J 1998, Dis-agreement: Politics and Philosophy, University of Minnesota Press, London.

Randolph, B. (2004) The Changing Australian City: New Patterns, New Policies and New Research Needs 1. Urban Policy and Research, 22(4), pp.481-93.

Ruming, K. (2011) Understandings of Social Mix and Community Opposition to Social Housing Constructed under the Nation Building Economic Stimulus Plan. Melbourne: State of Australian Cities 2011 Conference.

Ruming, K.J., Mee, K.J., \& McGuirk, P.M., (2004) Questioning the Rhetoric of Social Mix: Courteous Community or Hidden Hostility? Australian Geographical Studies, 42(2), pp.234248.

Ruming, K., Houston, D. \& Amati, M. (2012) Multiple Suburban Publics: Rethinking Community Opposition to Consolidation in Sydney, Geographical Research, 50(4), pp. 42135.

Shaw, K. (2005) The place of alternative culture and the politics of its protection in Berlin, Amsterdam and Melbourne, Planning Theory and Practice, 6(2), pp. 149-69.

Sturzaker, J. (2011). Can community empowerment reduce opposition to housing? Evidence from rural England. Planning Practice and Research, 26(5), pp. 555-570.

Takahashi, L.M., and Dear, M.J., (1997) The Changing Dynamics of Community Opposition to Human Service Facilities. Journal of the American Planning Association, 63(1), pp. 7993. 
Taylor, E.J. (2013) Do House Values Influence Resistance to Development?-A Spatial Analysis of Planning Objection and Appeals in Melbourne. Urban Policy and Research (ahead-of-print), pp. 1-22.

Tighe, J.R. (2010) Public Opinion and Affordable Housing: A Review of the Literature, Journal of Planning Literature, 25(1), pp. 3-17.

Tighe, J.R. (2012) How Race and Class Stereotyping Shapes Attitudes Toward Affordable Housing. Housing Studies, 27(7), pp. 962-83.

Tissot, S. (2014) '’"Loving diversity/controlling diversity: Exploring the ambivalent mobilization of upper-middle-class gentrifiers, South End, Boston. International Journal of Urban and Regional Research, 38(4), pp.1181-1194.

Turnbull, N. (2008) A taste of diversity—Letter to the Editor. Port Melbourne: The Emerald Hill Weekly.

Versteeg, W. and Hajer, M., (2010) Is this how it is, or is this how it is here? Making sense of politics in planning. In: Hillier, J., \& Healey, P., eds. The Ashgate Research Companion to Planning Theory: Conceptual challenges for spatial planning. Surrey: Ashgate, pp. 159-82.

Victorian Government (2014) Plan Melbourne: Metropolitan planning strategy. Melbourne: Victorian State Government.

Wolsink, M. (2006) Invalid theory impedes our understanding: a critique on the persistence of the language of NIMBY. Transactions of the Institute of British Geographers, 31(1), pp. 85-91.

Wolsink, M. (2007) Wind power implementation: the nature of public attitudes: equity and fairness instead of 'backyard motives'. Renewable and sustainable energy reviews, 11(6), pp. 1188-207. 